\title{
Nosocomial outbreak of disseminated orf infection in a burn unit, Gaziantep, Turkey, October to December 2012
}

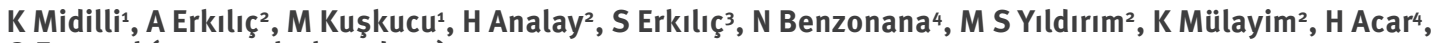

0 Ergonul (oergonul@ku.edu.tr) ${ }^{5}$

1. Istanbul University, Cerrahpaşa Medical School, Istanbul

2. Dr.Ersin Arslan Hospital, Gaziantep, Turkey

3. Gaziantep University, School of Medicine, Gaziantep, Turkey

4. Dr.Lütfü Kırdar Research and Tranining Hospital, Istanbul, Turkey

5. Koç University, School of Medicine, Istanbul, Turkey

Citation style for this article:

Midilli K, Erkılıç A, Kuşkucu M, Analay H, Erkılıç S, Benzonana N, Yıldırım MS, Mülayim K, Acar H, Ergonul O. Nosocomial Outbreak of Disseminated Orf Infection in a Burn Unit, Gaziantep, Turkey, October to December 2012. Euro Surveill. 2013;18(11):pii=20425. Available online: http://www.eurosurveillance.org/ViewArticle. aspx?Articleld $=20425$

We report the first outbreak of nosocomial orf infection in a hospital burn unit in Gaziantep, Turkey. The outbreak lasted from October to December 2012 and involved a total of thirteen cases. It demonstrates the risk of introduction of orf virus to a burn unit, and the potential for extensive transmission among patients with compromised skin integrity. The importance of hygiene measures and infection control are highlighted and possible transmission routes of the virus discussed.

On 30 October 2012, a patient was admitted to the burn unit of Dr. Ersin Arslan Community Hospital, Gaziantep, Turkey, after the Islamic feast of the sacrifice (el eid adha), which had started on 25 October 2012. The patient had been hospitalised in another local hospital before being transferred to the burn unit. Upon admission in the burn unit, the patient presented granulation at a burned skin site on the forearm. The lesions, that resembled a possible fungal infection, were not present on intact skin. On the way to recovery, all the epithelising burn injured areas of the patient were covered with papules, sparing the intact skin. Following the patient's hospitalisation, 12 patients subsequently admitted to the burn unit between 31 October and 25 November 2012 developed similar skin lesions and, unlike the first patient, also fever $\left(>38^{\circ} \mathrm{C}\right)$. The skin lesions occurred after a mean of 15 days (range: 8-26 days) from time of burn injury, and appeared on epithelising areas, sparing intact skin. Papules first developed at wound sites, which then progressed to pustules, weeping nodules, and finally to crusted lesions (Figure 1). Autologous skin grafts (originating from other sites of the same patient) were completely covered with the lesions, whereas intact skin areas remained unaffected. All patients had lymphadenomegaly, and disseminated skin lesions.
Gaziantep is the sixth biggest province of Turkey and located in the southeast part of Turkey, with a population of one and a half million. The Dr. Ersin Arslan Community hospital burn unit has 14 beds. The population it serves includes patients coming from rural areas and recently refugees from Syria. The hospital has an active infection control team which is responsible for appropriate surveillance and preventive measures.

The symptoms of the patients were compatible with orf disease, a zoonotic infection caused by a dermatotropic parapoxvirus that infects sheep and goats. Orf virus is transmitted to humans through contact with an infected animal or fomites. In humans, orf usually manifests as a solitary ulcerative skin lesion sometimes

\section{FIGURE 1}

Weeping nodules of orf disease in a patient of a burn unit, Gaziantep, Turkey, November 2012

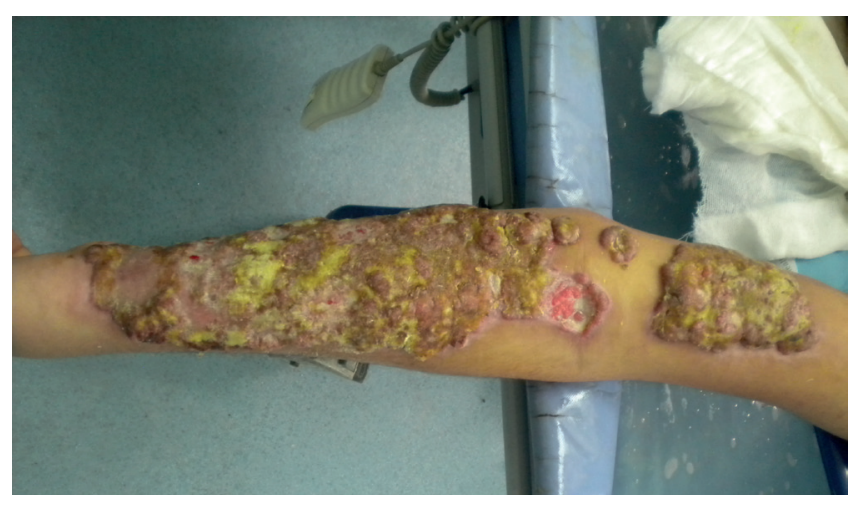




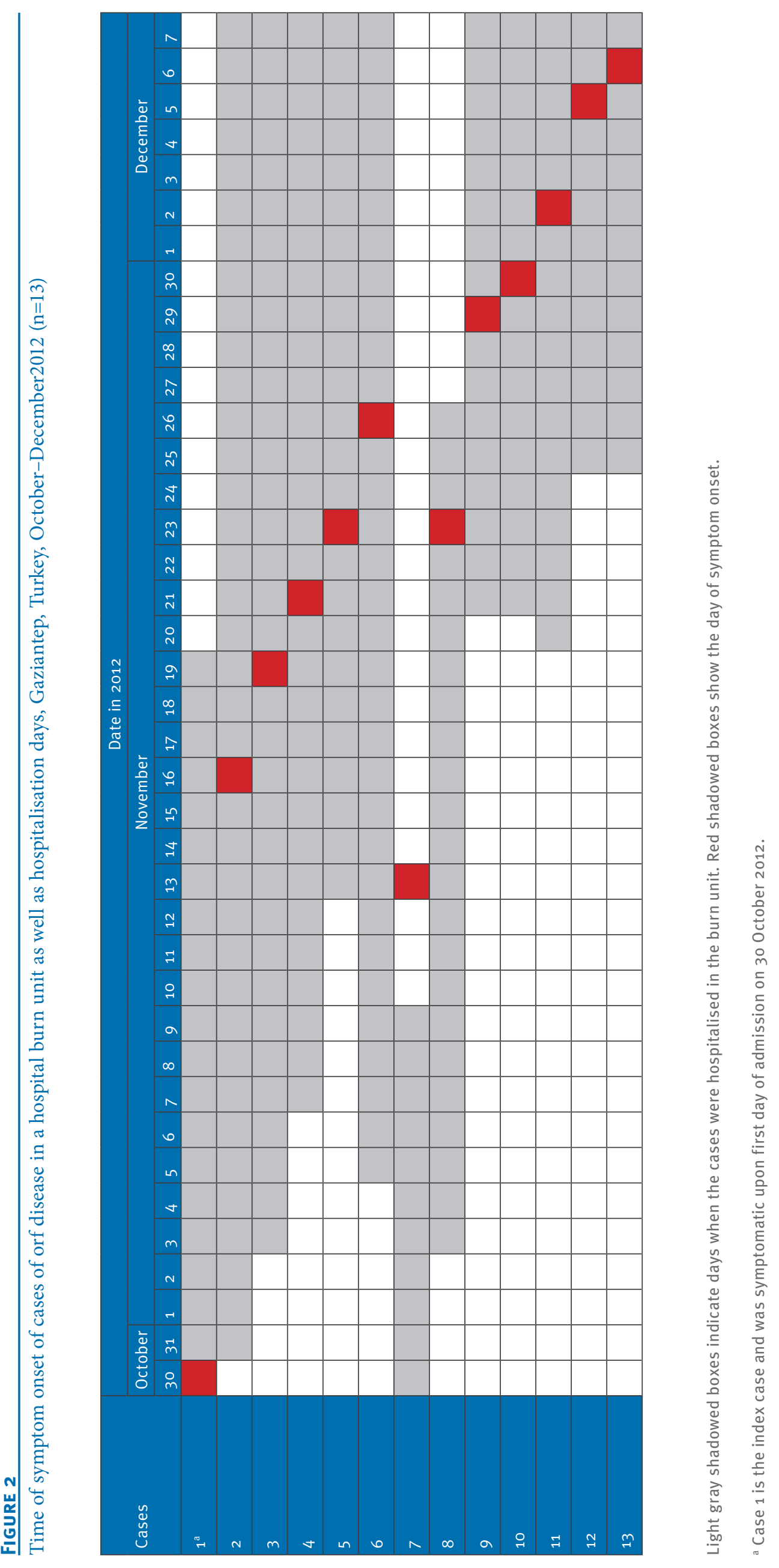




\section{FIGURE 3}

Phylogenetic analysis of partial B2L sequences derived from cases of orf disease in a burn unit, Gaziantep, Turkey, October-December2012

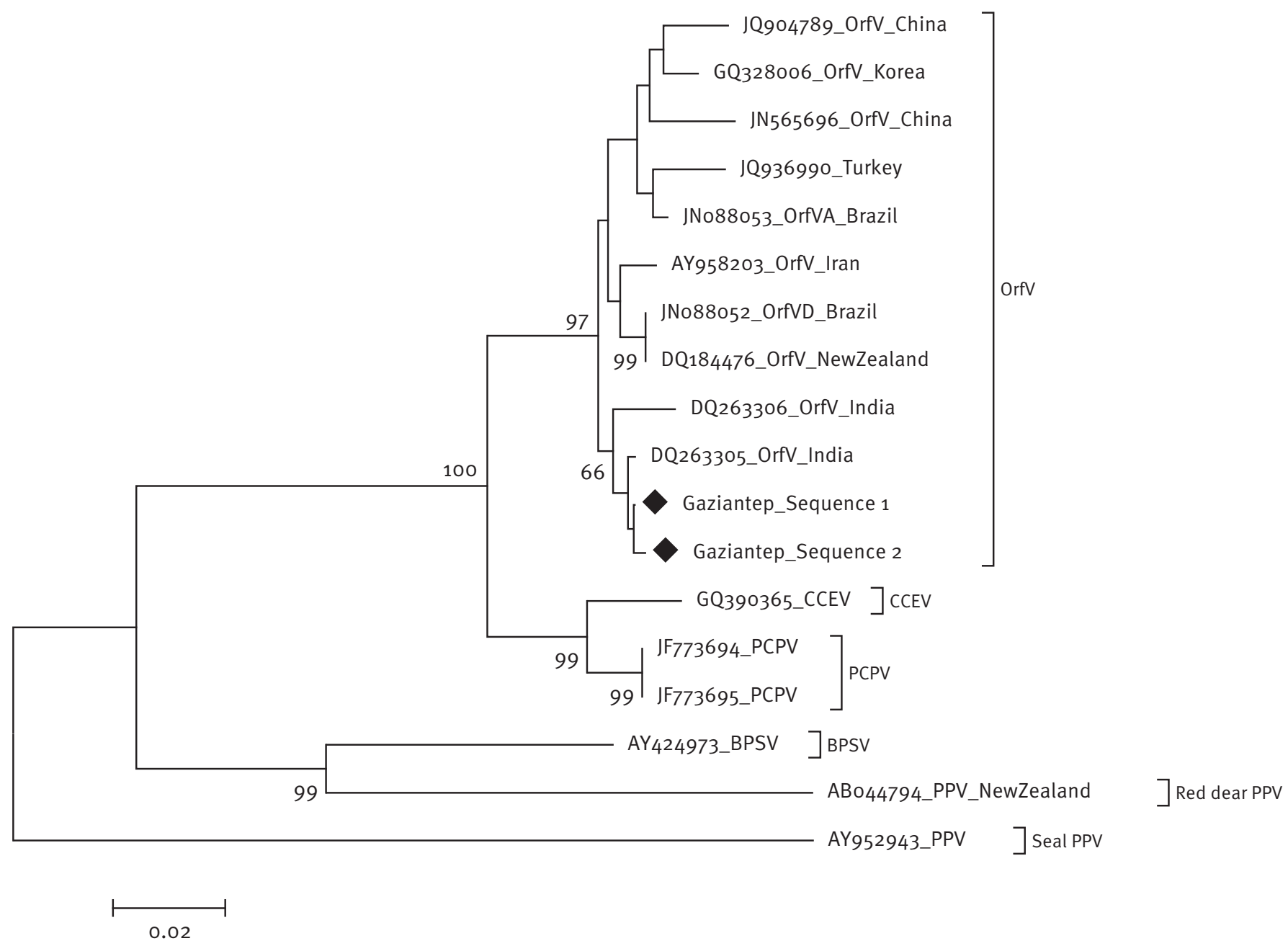

BPSV: bovine papular stomatitis virus; CCEV: camel contagious ecthyma virus; OrfV: orf virus; PCPV: pseudocowpox virus; PPV: parapoxvirus. The tree is based on partial $\mathrm{B} 2 \mathrm{~L}$ sequences ( $462 \mathrm{bp}$ ). Bootstrap values ( $50 \%$ only) are displayed above branches. Diamond shapes indicate the sequences of the cases in this study. Except for the sequences derived from the cases in this study, all OrfV sequences included in the phylogenetic tree are derived from infected animals.

resembling bacterial infection or neoplasm. The incubation period is three to seven days [1]. In Turkey, sporadic or small clusters of zoonotic cases have been described previously $[2,3]$. Human infection typically is acquired through animal contacts during occupational activities [4], or following the Islamic feast of the sacrifice (eid el adha) in Islamic communities [2,5-7].

Because the first symptomatic patient in the burn unit had been admitted shortly after the Islamic feast of the sacrifice, an outbreak orf disease was suspected and this prompted an investigation.

\section{Outbreak investigation and results}

The outbreak investigation included patients from the burn unit of Dr. Ersin Arslan Community Hospital, Gazantiep, who were hospitalised between 30 October 2012 and 2 January 2013.

The institutional review board (IRB) of Koç University approved the study. 
Number of cases of orf disease in a hospital burn unit as a function of time, Gaziantep, Turkey, October 2012-January 2013 $(n=13)$

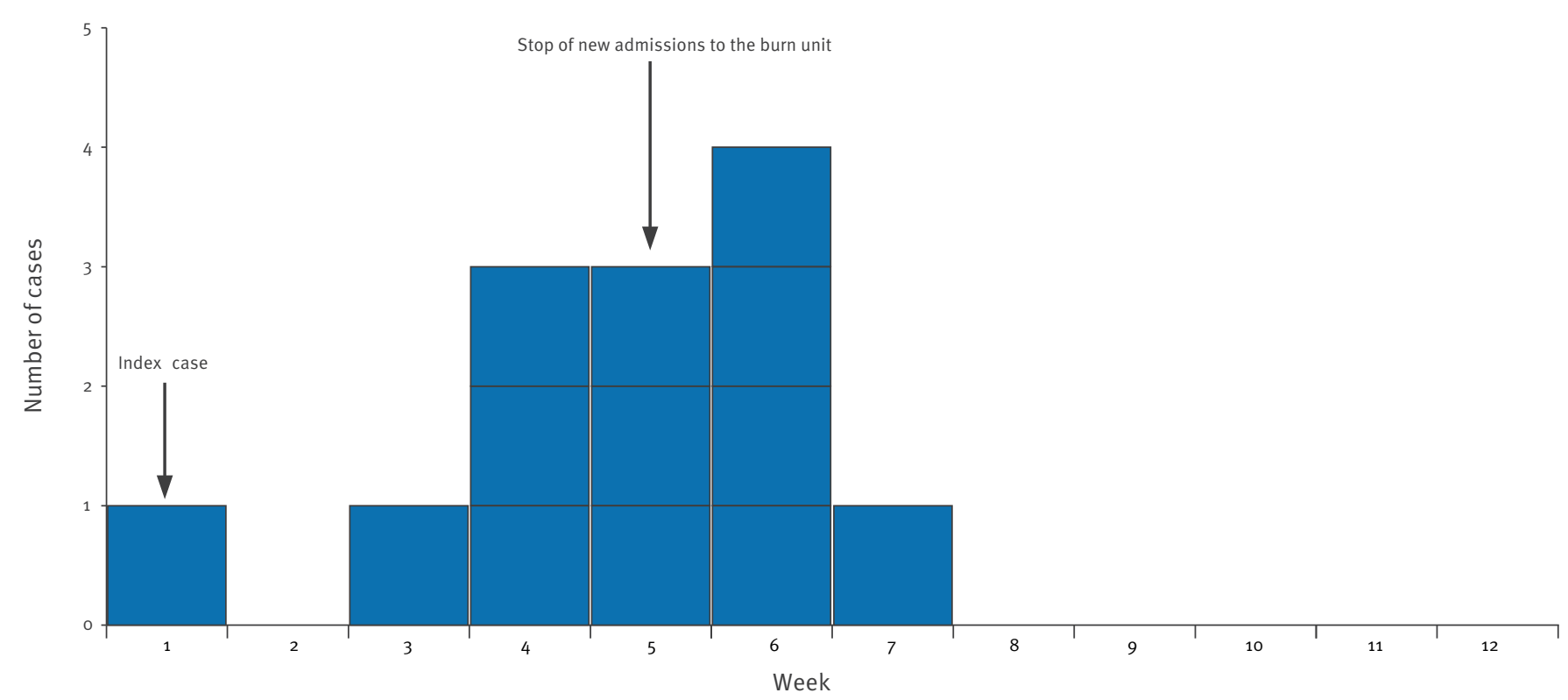

The week numbers are relative to the outbreak with week 1 ending on 31 October 2012.

Thirteen patients were included in total (Figure 2). Eleven of the $13(85 \%)$ patients were male, the mean age was 37 years (standard deviation: 19; minimum: 14, maximum: 69). All the patients were from Gaziantep, except three, who were from Syria. The median proportion of surface area burned was 20\% (range: $5 \%-60 \%$ ).

Swabs (from 9 patients) and/or biopsy specimens (from 13 patients) were taken from the lesions of case patients. Three environmental samples were collected including one from a water tank, one from a pair of scissors, and one from an ointment box in the wound dressing room. The patient samples and environmental samples were transported on ice to the laboratory and stored at $-70 \stackrel{\circ}{\circ}$ until processing. Nucleic acids were isolated with a commercial kit (High Pure Viral Nucleic Acid Extraction Kit, Roche, Germany). A nested polymerase chain reaction (PCR) protocol was used for detection of parapoxvirus DNA in samples [8]. The PCR products were purified by using EZ-10 Spin Column Gel Extraction kit (Bio Basic, Ontario, Canada) and sequenced bi-directionally on ABI-PRISM 310 Genetic Analyzer, using BigDye chemistry (Applied Biosystems, (A, USA). The sequences were edited and analysed using the SeqMan software (DNAStar Package Madison, USA) and two representative sequences were submitted to GenBank under accession numbers $\mathrm{KC}_{776922}$ and $\mathrm{KC}_{776923 *}$. The two representative outbreak sequences were subjected to phylogenetic analysis with the Molecular Evolutionary Genetics Analysis (Mega 5.1) software programme. A Neighbourjoining phylogenetic tree with 1,000 replicates using Kimura-2 parameter distance matrix was inferred from the outbreak sequences and 16 reference sequences obtained from GenBank.

Biopsy samples obtained from 13 patients and wound swabs from nine were positive for orf virus DNA. All patient sequences were identical except for sequences of two samples belonging to the same patient which differed at two positions among 462 bases. These nucleotide substitutions did not result in amino acid changes. The sequences from the outbreak cases clustered with Indian strains, but not with a strain previously reported from Turkey [9].

Orf viral DNA was detected from all three of the environmental samples. Patient and environmental samples were studied separately, and negative controls were included to each PCR batch to exclude the possibility of any cross-contamination.

\section{Control measures}

In our case, all infected patients were isolated, cohorted, and new patient admissions in the burn unit were stopped after 25 November (Figure 4). Since all environmental samples were positive for viral DNA, all surfaces were cleansed with hypochloride solution. 
The healthcare workers were educated on probable routes of transmission, with emphasis on patient to patient cross contamination and on appropriate use of personal protective equipment. Hands of caregivers were not screened. Poly-hexanide solutions were used as an antiseptic during wound care. No further case of orf infection was detected after 6 December 2012.

\section{Discussion and conclusions}

This is the first report of a nosocomial outbreak of orf infection, to our knowledge. Orf disease is usually known to have a benign course, but it can cause a serious problem in burn units because the skin integrity of patients is compromised on large surfaces and, utensils and the environment can be easily contaminated. Poxviruses can survive in animate and inanimate surfaces for years [10]. This property increases these viruses' capacity for nosocomial outbreaks. Parapox virus infections are usually zoonotic and nosocomial infections of poxviruses are rarely reported. A nosocomial buffalo poxvirus infection that spread between five burns units in Karachi, Pakistan was reported in 2007 [11]. The outbreak was hypothesised to be related to movement of patients between units. Control measures reduced transmission, but sporadic cases continued due to the admission of new patients with community-acquired infections [11].

All the environmental samples collected as a part of the current outbreak investigation were positive. Spillage of virus containing droplets during wound caring could be an explanation for such an extensive dissemination, however, transmission via the hands of caregivers might have taken place.

Nine of 13 (79\%) patients involved in the outbreak had secondary infections. Acinetobacter spp., Pseudomonas spp., Staphylococcus aureus, and Candida spp. were responsible for the superficial secondary infections. Two of $13(15 \%)$ patients died. Overall fatality rate of the unit within the last five years was around $2 \%$. Although the fatality rate during the outbreak was $15 \%$, the attribution of orf viral infection to the high fatality was not clear. The two fatal cases had both Pseudomonas and Acinetobacter infections, and probably died because of sepsis. Acinetobacter baumannii was isolated from blood culture of one of these cases. For the other patients, disease was self-limiting and symptoms disappeared within six weeks.

The sequences derived from orf virus infected patients in this outbreak did not cluster with a previously reported orf virus sequence from Turkey.

Although orf virus infection is a benign and self-limited disease, it can cause serious problems in burn units. This particular outbreak highlights the importance of strict hygiene in such settings. Infection control measures such as isolation, cohorting, and appropriate use of personal protective equipment should be carefully implemented. In this outbreak, after such measures were taken, as well as a temporary suspension of patient admissions to the burn unit, no further case was detected after 6 December 2012.

*Addendum:
The GenBank accession numbers were added on
15 March 2013.

Conflicts of interest

None declared.

Authors' contributions

Kenan Midilli: laboratory work, manuscript preparation; Ahmet Erkılıç: clinical work, infection control, manuscript preparation; Mert Kuşkucu: laboratory work, analysis; Harun Analay: clinical work; Suna Erkılıç: laboratory work; Nur Benzonana: manuscript preparation; M.Sait Yıldırım: laboratory work; Kamil Mülayim: clinical work; Hakan Acar: manuscript preparation; Önder Ergönül: manuscript preparation, analysis of data.

\section{References}

1. The Center for Food Security and Public Health (CFSPH). Contagious Ecthyma. Ames: CFSPH. [Accessed 13 Mar 2013]. Available from: http://www.cfsph.iastate.edu/Factsheets/ pdfs/contagious_ecthyma.pdf

2. Uzel M, Sasmaz S, Bakaris S, Cetinus E, Bilgic E, Karaoguz $A$, et al. A viral infection of the hand commonly seen after the feast of sacrifice: human orf (orf of the hand). Epidemiol Infect. 2005;133(4):653-7. http://dx.doi.org/10.1017/ So950268805003778. PMid:16050510 PMCid:2870292.

3. Erbağci Z, Erbağci I, Almila Tuncel A. Rapid improvement of human orf (ecthyma contagiosum) with topical imiquimod cream: report of four complicated cases. Dermatolog Treat. 2005;16(5-6):353-6. http://dx.doi. org/10.1080/09546630500375734. PMid:16428161.

4. Human Orf virus infection from household exposures United States, 2009-2011. MMWR Morb Mortal Wkly Rep. 2012;61(14):245-8. PMid:22495228.

5. Nougairede A, Fossati C, Salez N, Cohen-Bacrie S, Ninove L, Michel F, et al. Sheep-to-human Transmission of Orf Virus during Eid al-Adha religious practices, France. Emerg Infect Dis. 2013;19(1):102-5. http://dx.doi.org/10.3201/ eid1901.120421. PMid:23260031 PMCid:3557981.

6. Bayindir Y, Bayraktar M, Karadag N, Ozcan H, Kayabas U, Otlu $B$, et al. Investigation and analysis of a human orf outbreak among people living on the same farm. New Microbiol. 2011;34(1):37-43. PMid:21344145.

7. Sasmaz S, Uzel M, Sener S, Ucmak H. Rare presentation of human orf as multiple lesions. J Dermatol. 2011;38(8):8256. http://dx.doi.org/10.1111/j.1346-8138.2010.01082.x. PMid:21352318.

8. Abrahão JS, Lima LS, Assis FL, Alves PA, Silva-Fernandes AT, Cota MM, et al. Nested-multiplex PCR detection of Orthopoxvirus and Parapoxvirus directly from exanthematic clinical samples. Virol J. 2009;6:140. http://dx.doi. org/10.1186/1743-422X-6-140. PMid:19747382 PMCid:2749831

9. Karakas A, Oguzoglu TC, Coskun O, Artuk C, Mert G, Gul HC, Sener K, et al. First molecular characterization of a Turkish orf virus strain from a human based on a partial B2L sequence. Arch Virol. 2012 Dec 18. [Epub ahead of print]. http://dx.doi. org/10.1007/s00705-012-1575-5. PMid:23247915.

10. Knowles DP. Poxviridae. In: Maclachlan NJ, Dubovi EJ, editors. Fenner's Veterinary Virology, 4 ed. London: Elsevier; 2011.

11. Zafar A, Swanepoel R, Hewson R, Nizam M, Ahmed A, Husain A, et al. Nosocomial buffalopoxvirus infection, Karachi, Pakistan. Emerg Infect Dis. 2007;13(6):902-4. http://dx.doi.org/10.3201/ eid1306.061068. PMid:17553232 PMCid:2792849. 